\title{
Ascensão da Nova Direita e Colapso da Soberania Política
}

Fabrício Fontes de Andrade ${ }^{1}$

Pereira, P. A.P. (Org.). Ascensão da Nova Direita e Colapso da Soberania Política. Transfigurações da Política Social. São Paulo: Cortez, 2020. EPUB

Artigo enviado em abril de 2021

Artigo aprovado em agosto de 2021

Nesta primeira quadra deste novo século, a discussão de um projeto de sociedade implica necessariamente no debate sobre determinações que acarretaram o crescimento da chamada nova direita. O livro ${ }^{2}$ aqui resenhado aborda essa discussão passando pela definição de seu objeto: A ascensão da Nova Direita e o Colapso da Soberania. Esse debate está longe de ser simples. Além disso, a correlação de política social e a intervenção do Estado para garantir direitos fundamentais dos cidadãos é, também, um debate permeado por conceitos mal definidos na tentativa de delimitação da intercessão entre projeto econômico neoliberal e a dinâmica política da nova direita que emerge nesta cena histórica.

Apesar das dificuldades, o debate é relevante. Precisa ser enfrentado, e a obra o faz. Tendo em vista os elementos que conduzem as análises da ascensão da nova direita e suas consequências para a política social, nos deparamos nessa obra com um debate denso e rigoroso, articulando elementos teóricos e empíricos, que resultam da profundidade com que as autoras e autores desvelam a complexidade da ascensão da nova direita no cenário político mundial. Esse 
processo é apresentado, não em sua manifestação fenomênica, mas como uma consequência de transformações societárias, políticas, econômicas e institucionais.

A obra é composta por 08 artigos em duas partes que se complementam para demonstrar a regressão social na ordem capitalista e suas implicações para a cidadania. A primeira parte denominada de Aportes Analíticos Gerais é composta de 04 artigos que analisam delimitações mais amplas da temática que enreda a coletânea. A segunda parte Aportes Reflexivos e Propositivos sobre América Latina e o Brasil se direciona a questões estratégicas da luta social, a partir do contexto regional.

No primeiro bloco de textos destaca-se a centralidade das dinâmicas da politica social e dos direitos de cidadania no contexto de crise do capital, a subsunção da agenda do Estado às grandes corporações e o consequente avanço da extrema direita em âmbito global.

Esse bloco de textos a partir da complexidade da realidade analisada aponta a disputa política atual enquanto espetáculo cujo conteúdo emocional das narrativas se sobrepõe ao conteúdo substantivo da deliberação coletiva, sentido da democracia e da cidadania. O conteúdo esvaziado das disputas políticas apontado por J. Burgaya amplifica-se na esteira da massificação da economia digital e sua consequente concentração a par do aumento das vulnerabilidades, da devastação das esferas de sociabilidade e o avanço da fabricação de pós-verdades. Por sua vez, Marcos Siqueira elabora uma abordagem crítica da perspectiva da pós-modernidade, que antes de superar os aspectos deletérios identificados no "totalitarismo" da modernidade, consolida um processo amplo de mudança societária que ultrapassa a transformação de processos produtivos identificados com a chamada acumulação flexível. Essa nova dinâmica alicerçada na era da informação, da telemática, que intermedia produção e consumo, consolida consequências de manipulação por parte de partidos e grupos da vontade coletiva, que vão reverberar nas dinâmicas do Estado e da Sociedade Civil. 
A interlocução do avanço da nova direita na cena política e seus rebatimentos para a política social é afirmada nos dois artigos subsequentes. Se existe uma imprecisão na identificação entre neoliberalismo e o projeto político da nova direita, os dois últimos artigos tratam de dirimir tal fato. A organizadora da obra, Potyara Pereira, nos subsidia com elementos para a crítica ao discurso neoliberal/conservador que sedimenta uma perspectiva de política social individualista garantida via inserção mercadológica. A intervenção realizada por Camila Pereira aponta a hiperespetacularização do consumo e a ampliação da hegemonia do mercado, acentuando o fetichismo desse nas diversas esferas da vida social.

Esta diretiva de politica social restringe o Ethos solidário de classe, de politica pública e direito de cidadania, mediada por correlações de forças sociais no cânone democrático, por uma moral do individualismo possessivo, em que o cidadão é aquele proprietário de sua individualidade, sem qualquer compromisso coletivo. Diante das transformações ancoradas nas "revoluções" Corporativa, Gerencial e Financeira que geraram a dominância da classe rentista detentora de capital portador de juros, contrasta-se o ethos solidário de um lado e a moral individualista possessiva de outro; moral essa em que se firma a denominada "nova direita" a condensando e transformando-a em fato histórico (p.16). Essa dinâmica acarreta medidas restritivas da cidadania por meio de diversos partidos ao redor do mundo. Neste contexto, como destaca Camila Pereira, emergem os interesses personificados das grandes corporações, no mito "da superioridade moral e da maior capacidade gestora do mercado" (p.13).

A nova direita sintetiza elementos neoliberais - supremacia do mercado, competitividade, desigualdade social e desestruturação de políticas universalizantes - bem como elementos neoconservadores - nacionalismo, fundamentalismo religioso, família "tradicional" e discriminações em suas mais diversas expressões - avançando sobre conquistas sociopolíticas configuradas no ethos solidário. Diante do 
esvaziamento das pautas coletivas, exaltação do individualismo, e a dilapidação do caráter democrático, acarretam na confusão entre necessidades humanas e preferências individuais.

A segunda parte da obra propicia aportes analíticos e propositivos sobre o avanço da nova direita, levantando uma instigante e controversa questão norteadora dos textos: "quais os principais fatores que contribuem para que o avanço da esquerda seja tão pouco, nestes momentos, depois de conseguir impor sua hegemonia ao conjunto da sociedade?" (p.01) A instigante questão leva a uma redução da hegemonia ao processo de vitória eleitoral no continente latino americano. Se de fato a esquerda logrou vitórias eleitorais no pós-consenso de Washington, é forçoso inferir que essas vitórias tenham imposto a sua hegemonia - enquanto direção intelectual e moral - ao conjunto da sociedade. As experiências políticas da esquerda latino-americana, - apesar de seu imenso avanço vis a vis o prisma neoliberal ortodoxo - possibilitaram uma experiência de abrandamento neoliberal sem romper frontalmente com esse, fato que visualizamos nos espectros do social liberalismo latino-americano e no autodenominado neodesenvolvimentismo brasileiro.

O artigo de Maria A. César busca contribuições na elaboração teórica de J. Martí e na experiência socialista cubana, para destacar a centralidade das concepções de unidade, participação e resistência. Tal articulação objetiva lançar trincheiras para a luta cotidiana na sociedade capitalista para a construção de uma sociedade mais justa no contexto regional a luz da experiência socialista de Cuba. Por sua parte, Gilson Dantas realiza uma análise conjuntural da realidade regional apontando as dificuldades impostas à esquerda em construir um projeto que ultrapasse o viés reformista adotado por diversas experiências de governos locais frente a uma conjuntura econômica de aprofundamento da crise do capital desde 2008 em que simulacros de medidas keynesianas tem se reduzido na política monetária, identificando esse elemento no avanço da ascensão da direita em nível regional. 
O artigo de Marta Harnecker problematiza a questão que conduz o segundo bloco de textos: a mudança cultural necessária para nos colocar diante daqueles diversos setores que se contrapõe em alguma medida com a situação atual. Assim, a autora destaca o fardo cultural de submissão/imobilismo que consolida terreno fértil no qual frutifıcam valores burgueses mais individualistas na região. Contra o avanço desses valores a autora aponta a centralidade de um pensamento forte e combativo, ao mesmo tempo em que mobilizador e organizador, para conduzir uma transição social nas realidades nacionais, amplifıcando projetos coletivos.

Por sua vez, Lilian R. de Sousa encerra a obra resgatando a trajetória da formação do Estado capitalista brasileiro e o caráter regressivo da agenda dos direitos de cidadania na realidade nacional. No quadro político e social brasileiro, em que a agenda da extrema direita vem se impondo, elevam-se pautas com características cada vez mais repressivas, sustando inclusive os limites da emancipação política burguesa.

Considero fundamentais as contribuições da obra ao campo do pensamento social, que por meio de rigoroso aporte histórico e conceitual debate as determinantes do avanço da nova direita, suas repercussões para as políticas sociais e a dimensão da cidadania. Apesar de limites em apontar uma hegemonia da esquerda no cenário político regional, restringindo a categoria hegemonia ao contexto da democracia eleitoral, é destaque na obra o esforço prospectivo de linhas centrais para o enfrentamento do projeto neoconservador na realidade latino-americana. Por intermédio de um todo articulado, linguagem acessivel e atualidade do seu propósito, a obra vem ocupar lugar fundamental para a interpretação sobre a ascensão da nova direita e os desafios de seu enfrentamento na realidade latino-americana. 


\section{Notas}

1 Doutor em Serviço Social pelo Programa de Pós-graduação em Serviço Social da UFRJ; Docente do Curso de Serviço Social da Universidade Federal do Recôncavo da Bahia - UFRB; ORCID 0000-0001-5624-8222; e-mail: fabricio@ufrb.edu.br

2 "AAscensão da Nova Direita e o colapso da Soberania política: Transfigurações da Política Social", organizado por Potyara Pereira, docente da Universidade de Brasília - UnB. É uma coletânea de textos e analíticos sobre o avanço político da nova direita e os seus reflexos na representatividade da soberania e das instituições do Estado-nação. 